\title{
Proximate and Major Minerals Components of the Edible Pulp of Momordica charantia Fruit
}

\author{
Samba Balde ${ }^{1,2}$, Nicolas Cyrille Ayessou ${ }^{1,2 *}$, Oumar Ben Khatab Cisse ${ }^{1,2}$, Papa Guedel Faye ${ }^{1,2}$, \\ Mady Cisse ${ }^{1,2}$, Codou Mar Diop ${ }^{1,2}$ \\ ${ }^{1}$ Ecole Supérieure Polytechnique, University Cheikh Anta Diop, Dakar, Sénégal \\ ${ }^{2}$ Centre d'Etudes sur la Sécurité Alimentaire et les Molécules Fonctionnelles (CESAM), Université Cheikh Anta Diop, Dakar, Sénégal \\ Email: balsamba2013@yahoo.fr, *nicolas.ayessou@ucad.edu.sn, *nayessou@yahoo.fr, cisse87ouma r@hotmail.com, \\ guedougui@hotmail.com,mady.cisse@ucad.edu.sn,cgmare@gmail.com
}

How to cite this paper: Balde, S., Ayessou, N.C., Cisse, O.B.K., Faye, P.G., Cisse, M. and Diop, C.M. (2020) Proximate and Major Minerals Components of the Edible Pulp of Momordica charantia Fruit. Food and Nutrition Sciences, 11, 32-39.

https://doi.org/10.4236/fns.2020.111004

Received: June 8, 2019

Accepted: January 4, 2020

Published: January 7, 2020

Copyright $\odot 2020$ by author(s) and Scientific Research Publishing Inc. This work is licensed under the Creative Commons Attribution International License (CC BY 4.0).

http://creativecommons.org/licenses/by/4.0/

\begin{abstract}
Momordica charantia (Cucurbitaceae), is a plant commonly used in traditional medicine in Senegal whose fruits are weakly consumed by the population. However, no data exists on the nutritional intake of the latter. This work aims to determine the physicochemical and biochemical characteristics of the pulp of Momordica charantia. The study focused on two lots of fruits from two geographically different regions of Senegal (Dakar and Fatick). The biochemical analyses of the pulp showed average values of protein from $2.39 \pm$ $0.01 \mathrm{~g} / 100 \mathrm{~g}$ to $3.19 \pm 0.01 \mathrm{~g} / 100 \mathrm{~g}$; reducing sugar from $4.22 \pm 0.10 \mathrm{~g} / 100 \mathrm{~g}$ to $3.55 \pm 0.10 \mathrm{~g} / 100 \mathrm{~g}$; totals sugar from $4.43 \pm 0.02 \mathrm{~g} / 100 \mathrm{~g}$ to $3.38 \pm 0.58 \mathrm{~g} / 100$ g. The average contents of polyphenol and flavonoids were respectively from $1.91 \pm 0.04 \mathrm{~g} / 100 \mathrm{~g}$ to $1.04 \pm 0.09 \mathrm{~g} / 100 \mathrm{~g}$ and $32.59 \pm 0.04 \mathrm{mg} / 100 \mathrm{~g}$ and $20.75 \pm 1.19 \mathrm{mg} / 100 \mathrm{~g}$. According to these results, the fruit of $M$. charantia may be considered as rich in antioxidant. At the opposite, it is very weak in mineral elements, such as calcium and potassium $(1.01 \mathrm{mg} / 100 \mathrm{~g} ; 3.38$ $\mathrm{mg} / 100 \mathrm{~g}$ ). Meanwhile, the seeds content $24 \%$ of lipids. Thus, investigations should be done on its biological proprieties, physical and biochemical components.
\end{abstract}

\section{Keywords}

Momordica charantia, Characterization, Pulp

\section{Introduction}

The specie belonging to the Cucurbitaceae family, is commonly called gourd or "bitter gourd", linked to bitter compounds contained in all parts of the plant including the fruit [1]. Momordica charantia is widely cultivated in the tropical 
and subtropical regions of the world, such as India, Malaysia, China, Thailand, Japan, and Senegal [2] [3] [4]. The fruit of $M$. charantia is oblong or base with buds and resembles a small cucumber that has been used for nutritional and medicinal purposes [1] [5]. The young fruit is emerald green which becomes orange when ripe [5], while the flesh becomes scarlet white during maturation. Immature fruit is commonly used as a vegetable and is a good source of vitamin C, vitamin A, calcium ( 38 to $41 \mathrm{mg}$ ), potassium (20 to $37 \mathrm{mg}$ ) and phosphorus (191 to $407 \mathrm{mg}$ ) [3] [5]. However, there is no data on the nutritional value of the ripe fruit. In some countries of West Africa, the fruit is also consumed as supplementary or emergency food [6]. Recent studies have proven the medicinal properties of fruits and seeds as anti-HIV, anti-ulcer, anti-inflammatory [7], anti-leukemic, anti-microbial, anti-tumor [8] and anti-diabetic [9] [10]. Many of these traditional plants are used without any attention to their nutritional values [11]. This work aims to characterize the pulp of M. charantia ripe fruit grown in Senegal in order to appreciate its potential nutritional components.

\section{Material and Methods}

\subsection{Raw Materials}

Our study focused on two samples of Momordica charantia fruit harvested in 2018 at two sites of Senegal. The first comes from Fatick (middle region) and the second from Dakar (western region called Niayes) (Figure 1). These two regions were chosen according to previous informations on ethnobotanical studies showing that Momordica is well known and used in those areas of Senegal. On the other land, pedoclimatic conditions of these regions are different. The selected sample represents the whole population. Indeed, it is a descriptive cross-sectional study carried out in these two regions of Senegal since November 2017 through an ethnobotanical survey in these regions. The collected masses represented $1 \mathrm{~kg}$ for the physicochemical and biochemical analyzes of the pulp. The different parts of the fruit are summarized in Figure 2 with a) the whole fruit, b) the fruit which opens in three valves, leaving the pulp and the seeds bare, and c) the pulp separated from the seeds.

\subsection{Physicochemical and Biochemical Analyzes}

The proportions of the various constituents of the fruit (pulp, seeds, and pericarp) were determined by weighing. For each sample, the mass measurements were carried out five times on $100 \mathrm{~g}$ of fruit. Soluble solids were measured (brix degree) using a digital hand refractometer (ATAGO Pocket PAL- $\alpha$, Japan). Trials were repeated three (3) times for each lot. The $\mathrm{pH}$, titratable acidity, soluble solids content, reducing sugars and total sugars were evaluated according to AFNOR's methods standard (NF V76-122) [12]. The total polyphenols were characterized by UV/visible spectrophotometry according to the method of Georgé [13]. The browning index was determined by the $L^{\star} a^{\star} b$ system [14] using a laboratory colorimeter. Total minerals were carried out according to the 


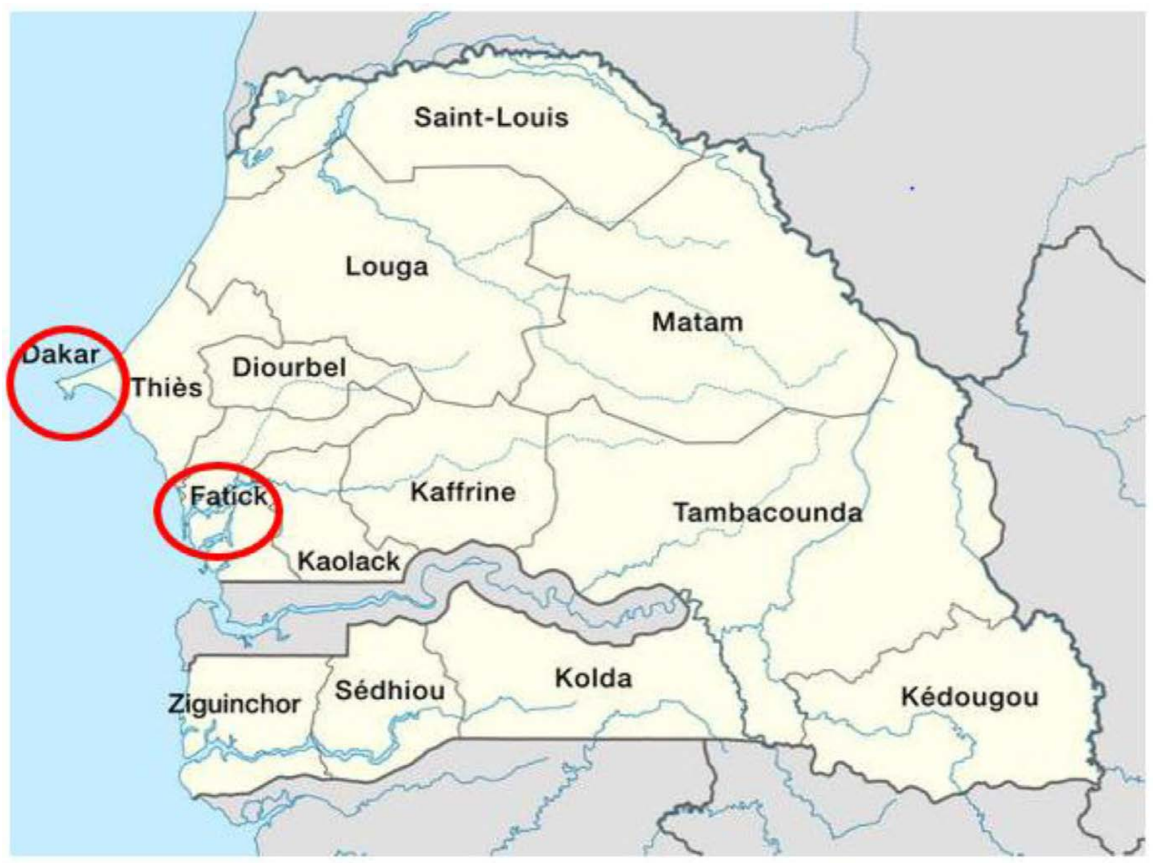

Figure 1. Sample collection regions (Dakar and Fatick).
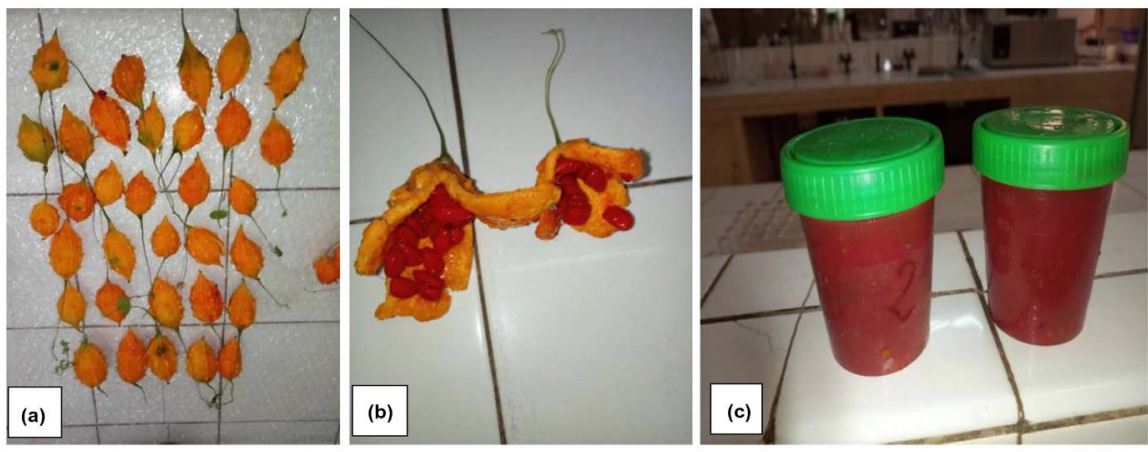

Figure 2. Momordica charantia: fruit (a), open fruit (b), pulp (c).

procedure standard AFNOR (NF V76-122, 1994) [12]. The nitrogen determination was carried out according to the Kjeldhal method (standard NF 03-050) and the proteins were calculated with a coefficient of 5.7.

\subsection{Statistical Analyzes}

The one-way analysis of variance (ANOVA) tests used in this research work was performed with the STATISTICA 7.1 software. The objective is to compare the significance of the analytical results of the samples for each parameter. Statistical differences with a probability value less than $0.05(P<0.05)$ are considered significant.

\section{Results and Discussion}

\subsection{Proportions of the Constituents of the Fruit}

Samples have a similar percentage of pulp and seed mass compared to whole 
fruit (Figure 3). However, the mass of pulp (11.24\%) is relatively smaller than the seeds one (13\%).

\subsection{Physicochemical and Biochemical Characterizations}

The results of physicochemical, biochemical and nutritional characterizations obtained on the pulp are presented in Table 1 and Table 2. The pulp of the fruit of $M$. charantia is weakly acidic with a $\mathrm{pH}$ of around 5 . This corresponds to a maximum titratable acidity of $2.67 \mathrm{mEq} / 100 \mathrm{~g}$. The reducing and total sugar contents of the Dakar and Fatick samples are respectively $4.22 \pm 0.01 \mathrm{~g} / 100 \mathrm{~g}$ and $3.55 \pm 0.01 \mathrm{~g} / 100 \mathrm{~g}$ and $4.43 \pm 0.02 \mathrm{~g} / 100 \mathrm{~g}$ and $3.38 \pm 0.58 \mathrm{~g} / 100 \mathrm{~g}$. The concentrations of polyphenols and flavonoids are respectively $1.91 \pm 0.04 \mathrm{~g} / 100$ $\mathrm{g}$ and $20.75 \pm 0.04 \mathrm{mg}$ catechin $/ 100 \mathrm{~g}$ for Dakar's samples; $1.04 \pm 0.09 \mathrm{~g} / 100 \mathrm{~g}$ and $32.59 \pm 1.19 \mathrm{mg}$ catechin $/ 100 \mathrm{~g}$ for Fatick's samples. Both samples show significant differences for all parameters except $\mathrm{pH}$, acidity and brown index.

The pulp is not acidulous which is confirmed by a high $\mathrm{pH}$. These results are consistent with those found in Mexico by Jacobo-Valenzuela et al., (2011) [15] on 95 bitter squash belonging to the cucurbitaceous family where the $\mathrm{pH}$ varies between 4.27 and 5.89. This is in agreement with the results obtained by Kone et al., (2018) [16] $(\mathrm{pH}=5.11)$ on the pulp of black plum fruit. The results of ANOVA showed that $\mathrm{pH}$, acidity, edible proportion and brown index did not vary despite the various provenances of the samples. However, it is well known that pedoclimatic conditions, the stage of maturity of the fruit at harvest and the storage conditions of the pulp, might influence the physicochemical parameters.

The soluble solids content of the fruits represents the soluble compounds in water: sugars, acids, vitamin $\mathrm{C}$, amino acids, etc. This is an important qualitative characteristic for post-harvest screening of certain fruits. As the sugar content generally increases as the fruit matures, the soluble sugar content is an index of ripeness. We obtained $6.6 \mathrm{~g} / 100 \mathrm{~g}$, a low value compared to the black plum (18.83 $\pm 0.11 \mathrm{~g} / 100 \mathrm{~g})$ found by Kone et al., (2018) [16].

For total sugars (ST) and reducing sugars, there is a significant variation in the level of sugars from one region to another $(4.43 \mathrm{~g} / 100 \mathrm{~g}$ and $3.38 \mathrm{~g} / 100 \mathrm{~g})$ and $(4.22 \mathrm{~g} / 100 \mathrm{~g}$ and $3.55 \mathrm{~g} / 100 \mathrm{~g})$. These values are higher than those found by Koné on black plum pulp in Ivory Coast $(11.60 \mathrm{mg} 100 \mathrm{~g}$ and $34.67 \mathrm{mg} / 100 \mathrm{~g})$

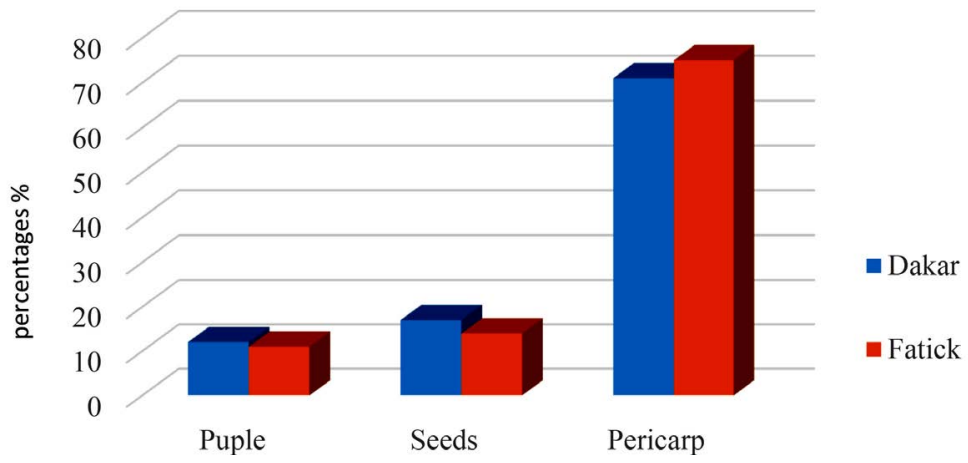

Figure 3. Ratio of different parts of $M$. charantia fruits. 
Table 1. Physicochemical and biochemical characteristics of $M$. charantia pulp.

\begin{tabular}{ccc}
\hline Settings & Dakar & Fatick \\
\hline Fruit pulp (g) & $11.29 \pm 2.17^{\mathrm{a}}$ & $11.34 \pm 3.05^{\mathrm{a}}$ \\
$\mathrm{pH}$ & $5.85 \pm 0.04^{\mathrm{a}}$ & $5.92 \pm 0.01^{\mathrm{a}}$ \\
Titratable acidity (mEq/100 g) & $2.67 \pm 0.24^{\mathrm{a}}$ & $2.43 \pm 0.49^{\mathrm{a}}$ \\
Soluble dry extract (g/100 g) & $6.6 \pm 0.01^{\mathrm{a}}$ & $6.6 \pm 0.01^{\mathrm{a}}$ \\
Brown index & $189.42 \pm 25.27^{\mathrm{a}}$ & $198.17 \pm 0.71^{\mathrm{a}}$ \\
Protein (g/100 g) & $2.39 \pm 0.01^{\mathrm{a}}$ & $3.19 \pm 0.01^{\mathrm{b}}$ \\
Reducing sugars (g/100 g) & $4.22 \pm 0.01^{\mathrm{a}}$ & $3.55 \pm 0.01^{\mathrm{b}}$ \\
Total sugars (g/100 g) & $4.43 \pm 0.02^{\mathrm{a}}$ & $3.38 \pm 0.58^{\mathrm{b}}$ \\
polyphenols (gallic acid g/100 g) & $1.91 \pm 0.04^{\mathrm{a}}$ & $1.04 \pm 0.09^{\mathrm{b}}$ \\
Flavonoids (catechin $\mathrm{mg} / 100 \mathrm{~g})$ & $20.75 \pm 0.04^{\mathrm{a}}$ & $32.59 \pm 1.19^{\mathrm{b}}$ \\
\hline
\end{tabular}

$\mathrm{Nb}$ : $\mathbf{a}, \mathbf{b}$ : for the same type of samples with the same column, the means of the values followed by a different letter are significantly different for a threshold of $P<5 \%$.

Table 2. Mineral elements of $M$. charantia pulp.

\begin{tabular}{ccc}
\hline Mineral elements $(\mathrm{mg} / \mathbf{1 0 0} \mathrm{g})$ & Dakar & Fatick \\
\hline Sodium & $0.32 \pm 0.01$ & $0.33 \pm 0.01$ \\
Potassium & $3.38 \pm 0.01$ & $4.57 \pm 0.01$ \\
Magnésium & $0.27 \pm 0.01$ & $0.50 \pm 0.01$ \\
Calcium & $1.01 \pm 0.01$ & $1.80 \pm 0.01$ \\
\hline
\end{tabular}

[16]. The fruits from Dakar are the richest in sugar than those of Fatick. However, the total and reducing sugar content of $M$. charantia fruits remains lower than that of jujube (Zizyphus mauritiana Lam) $(7.4 \mathrm{~g} / 100 \mathrm{~g}$ and $23.6 \mathrm{~g} / 100 \mathrm{~g})$ in Senegal [17]. The total polyphenol content is $1.91 \pm 0.04 \mathrm{mg} \cdot \mathrm{Eq} \cdot \mathrm{AG} / 100 \mathrm{~g}$ for Dakar fruits, $1.04 \pm 0.09 \mathrm{~g} / 100 \mathrm{~g}$ for Fatick fruits. Statistical analysis shows that these values are significantly different. These values are low compared to those found by Cisse et al., on Adansonia pulp [18] (329 mg/100 g) and Koné on black plum fruit pulp (193.33 $\pm 0.03 \mathrm{mg} \cdot \mathrm{Eq} \cdot \mathrm{AG} / 100 \mathrm{~g})[16]$.

These polyphenols act as antioxidants in different ways by inhibiting cell potential and lipid degradation generated by free radicals [19]. Polyphenols also protect against degenerative diseases, certain cancers and cardiovascular diseases [20]. The total flavonoid values are statistically different for all regions studied with $20.75 \pm 0.04$ catechin $\mathrm{mg} / 100 \mathrm{~g}$ for Dakar and $32.59 \pm 1.19$ catechin $\mathrm{mg} / 100$ $\mathrm{g}$ for fatick. This concentration is an asset to health as the flavonoids, protect the blood vessels from damage related to cholesterol [21]. Flavonoids also are endowed with hypoglycemic and antidiabetic properties according to [22]. In addition, several studies have shown that the consumption of flavonoid-rich foods is inversely correlated with the risk of developing cardiovascular diseases [23]. Therefore regular consumption of the pulp of $M$. charantia could help to avoid disorders related to oxidative stress such as degenerative diseases. The results of 
the mineral elements are summarized in Table 2. The latter are present in appreciable quantities with contents of potassium $(3.38 \pm 0.01 \mathrm{mg} / 100 \mathrm{~g}$ and $4.57 \pm$ $0.01 \mathrm{mg} / 100 \mathrm{~g})$ and calcium $(1.01 \pm 0.01 \mathrm{mg} / 100 \mathrm{~g}$ and $1.80 \pm 0.01 \mathrm{mg} / 100 \mathrm{~g})$ (Table 2). The results of this study indicate that potassium and calcium values are lower than those found by Mohammed et al., (2014) [24] in Nigeria on $\mathrm{Cu}$ curbita Maxima pulp $(184.34 \pm 1.24$ and $27.63 \pm 0.09)$. It has been reported that high levels of potassium in the body increase the use of iron [25] and are beneficial for people taking diuretics to control hypertension and suffer from excessive body fluid excretion [26]. Calcium is a constituent of bones and helps the body to contract properly, blood clots and nerves to transmit messages [27]. The calcium values of this plant are below the Food Reference Intensity (FRI) of 1000 $\mathrm{mg} /$ day for women 19 years of age at menopause and men 65 years of age. [28]. The potassium content of the pulp is $3.38 \pm 0.01 \mathrm{mg} / 100 \mathrm{~g}$ and $4.57 \pm 0.01$ $\mathrm{mg} / 100 \mathrm{~g}$. It is the most abundant mineral as in baobab pulp and most plants [18]. These neglected fruits of $M$. charantia seem to present no famous proximate components interests.

\section{Conclusion}

This study showed a strong variation in the biochemical, mineral and nutritional characteristics of these different samples of $M$. charantia. The pulp of M. charantia presents a nutritional interest according to polyphenols contents. However, the pulp remains poor in either major components or nutrients, but the seed should lead researches on the quality of its oil.

\section{Conflicts of Interest}

The authors declare no conflicts of interest regarding the publication of this paper.

\section{References}

[1] Basavaraj, S.A. and Siva, R.E. (2017) Momordica charantia of Phytochemical Study: A Review. International Journal of Homoeopathic Sciences, 1, 1-4.

[2] Balde, S., Ayessou, N.C., Gueye, M., Ndiaye, B., Sow, A., cisse, O.I.K., Cisse, M. and Diop, C.G.M. (2019) Investigations Ethnobotaniques de Momordica charantia Linn (Cucurbitaceae) au Sénégal. International Journal of Biology and Chemical Sciences, 13, 466-474. https://doi.org/10.4314/ijbcs.v13i1.37

[3] Sorifa, A.M. (2018) Nutritional Compositions, Health Promoting Phytochemicals and Value Added Products of Bitter Gourd: A Review. International Food Research Journal, 25, 1763-1772.

[4] Jia, S., Shen, M., Zhang, F. and Xie, J. (2017) Recent Advances in Momordica charantia. International Journal of Molecular Sciences, 18, 2555. https://doi.org/10.3390/ijms18122555

[5] Hyun, Y.K., So-Youn, M., Su, H.K., Dong, G., Eun, J.C. and Sanghyun, L. (2013) Phytochemical Constituents of Bitter Melon (Momordica charantia). Natural Product Sciences, 19, 286-289.

[6] Nelvana, R. and Fawzi, M.M. (2014) The Therapeutic Potential of Medicinal Foods. 
Advances in Pharmacological Sciences, 2014, Article ID: 354264. https://doi.org/10.1155/2014/354264

[7] Chao, C.Y., Sung, P.J., Wang, W.H. and Kuo, Y.H. (2014) Anti-Inflammatory Effect of Momordica charantia in Sepsis Mice. Journal of Molecules, 19, 12777-12788. https://doi.org/10.3390/ijms18122555

[8] Massimo, B., Daniele, M. and Letizia, P. (2019) Momordica charantia, a Nutraceutical Approach for Inflammatory Related Diseases. Frontiers in Pharmacology, 10, 48 .

[9] Ahamad, J., Saima, A. and Showkat, R.M. (2017) Review Article Momordica charantia Linn. Review on Phytochemistry and Pharmacology. Research Journal of Phytochemistry, 11, 53-65. https://doi.org/10.3923/rjphyto.2017.53.65

[10] Verma, V.N. (2015) Chemical Composition and Quantitative Elemental Investigation of Bitter Melon. World Scientific News, 16, 84-94.

[11] Baby, J. and Jini, D. (2013) Antidiabetic Effects of Momordica charantia (Bitter Melon) and Its Medicinal Potency. Asian Pakistan Journal Tropical Diseases, 3, 93-102. https://doi.org/10.1016/S2222-1808(13)60052-3

[12] (AFNOR) French Association of Normalization (1982) Products Derived from Fruit and Vegetable Juices. AFNOR, Paris, France, 327.

[13] Georgé, S., Brat, P., Alter, P. and Amiot, M.J. (2005) Rapid Determination of Polyphenols and Vitamin C in Plant-Derived Products. Journal of Agricultural and Food Chemistry, 53, 1370-1373. https://doi.org/10.1021/jf048396b

[14] (AFNOR) French Association of Normalization (2011) Colorimetry Part 4: Chromatic Space L a b CIE 1976. AFNOR, Paris, France, 8.

[15] Jacobo-Valenzuela, N., Maróstica-Junior, M.R., Zazueta-Morales, José, J. and Gallegos-Infante J.A. (2011) Physicochemical, Technological Properties, and HealthBenefits of Cucurbita moschata. Food Research International, 44, 2587-2593. https://doi.org/10.1016/j.foodres.2011.04.039

[16] Kone, H.S. (2018) Caractérisation Biochimique de la pulpe des fruits du prune noir. European Scientific Journal, 14, 252-270. https://doi.org/10.19044/esj.2018.v14n3p252

[17] Danthu, P., Solovievc, P., Tottéc, A., Tinee, E., Ayessou, N., Gaye, A., Niang, T.D., Seck, M. and Fall, M. (2002) Caractères physico-chimiques et organoleptiques comparés de jujubes sauvages et des fruits de la variété Gola introduite au Sénégal. Fruits, 57, 173-182. https://doi.org/10.1051/fruits:2002016

[18] Cissé, I., Montet, D., Reynes, M., Danthu, P., Yao, B. and Boulanger, R. (2013) Biochemical and Nutritional Properties of Baobab Pulp from Endemic Species of Madagascar and the African Mainland. African Journal of Agricultural Research, 8, 6046-6054.

[19] Hasan, M. and Ahmad, N. (2000) Tea Polyphenols: Prevention of Cancer and Optimizing Health. American Journal of Clinical Nutrition, 71, 1698-1702. https://doi.org/10.1093/ajcn/71.6.1698S

[20] Augustin, S., Ian, T.J. and Saltmarsh, M. (2005) Polyphenols: Antioxidants and Beyond. American Journal of Clinical Nutrition, 81, 215S-217S. https://doi.org/10.1093/ajcn/81.1.215S

[21] Abdou, B.A. (2009) Contribution à l'étude du développement d'un aliment fonctionnel à base d'épices du Cameroun : Caractérisation physico-chimique et fonctionnelle. Institut National Polytechnique de Lorraine, Université De Ngaoundere, Ensai, 228 p. 
[22] Kebieche, M. (2009) Activité biochimique des extraits flavonoïdiques de la plante Ranunculus repens L.: Effet sur le diabète expérimental et l'hépatotoxicité induite par l'Epirubicine. Thèse de Doctorat en Biochimie, Université Mentouri Constantine, Constantine, Algeria.

[23] Pier-Giorgio, P. (2000) Flavonoids as Antioxidants. Journal Natural of Product, 63, 1035-1042. https://doi.org/10.1021/np9904509

[24] Mohaammed, S.S., Paiko, Y.B., Mann, A., Ndamitso, M.M., Mathew, J.T. and Maaji, S. (2014) Proximate, Mineral and Anti-Nutritional Composition of Cucurbita Maxima Fruits Parts. Nigerian Journal of Chemical Research, 19, 37-49.

[25] Jacob, A.G., Etong, D.I. and Tijjani, A. (2015) Proximate, Mineral and Anti-Nutritional Compositions of Melon (Citrullus lanatus) Seeds and Pulp. British Journal of Research, 2, 142-151.

[26] Habtamu, F.G., Gulelat, D.H., Fekadu, B., Ashagrie, Z. and Sudip, K.R. (2016) Proximate, Mineral, and Antinutrient Compositions of Indigenous Okra (Abelmoschus esculentus) Pod Accessions: Implications for Mineral Bioavailability. Food Science \& Nutrition, 4, 223-233. https://doi.org/10.1002/fsn3.282

[27] Daniel, V.N., Daniang, I.E. and Nimyel, N.D. (2011) Phytochemical Analysis and Mineral Elements Composition of Ocimum basilicum Obtained in Jos Metropolis, Plateau State, Nigeria. International Journal of Engineering \& Technology, 11, 161-165.

[28] Joint FAO/WHO (2002) Working Group Report on Drafting Guidelines for the Evaluation of Probiotics in Food. London, Ontario, Canada. 